Opini

\title{
PEMBELAJARAN BERBASIS \\ BERPIKIR KRITIS DAN KREATIF
}

\author{
Yurniwati
}

\begin{abstract}
In this $20^{\text {th }}$ century education is demanded to be able to in counter all changes and development in all aspect of life. The advancement of technology which develops very fast as encourages the development of science and technology. To anticipate and face all kinds of development, the teachers should prepare the children to follow the development of sciences and technology.

Now days the students should receive all information from the teachers critically. They also expected to be involve mentally in constructing knowledge. One of the tools to enable the student to construct knowledge is ability to think critically and creatively revering to the research conducted by ALPS therefore approaches that can be taken to train ability to think critically and creatively. They are thinking thematic thinking, disposotioning thinking, transfering thinking, and assesing thinking.
\end{abstract}

Kata Kunci : pembelajaran, keterampilan berpikir, berpikir kreatif, berpikir kritis

\section{PENDAHULUAN}

Pembelajaran melibatkan berpikir dan tergantung kepada bagaimana kualitas berpikir siswa tentang apa yang telah dipelajarinya. Contoh: siswa yang selalu menekankan kepada menghubungkan ide dengan sesuatu yang telah diketahuinya, mencari penjelasan tersembunyi atau berpikir tentang kekuatan atau kelemahan dalam pemikirannya akan membuat pemahaman yang mendalam tentang subjek lintas kurikulum daripada siswa yang hanya pasif menerima informasi.

Pembelajaran yang menekankan kepada berpikir percaya bahwa belajar adalah konsekuensi dari berpikir dengan baik. Berpikir yang baik dapat dipelajari oleh semua siswa. Belajar tidak diartikan dengan anak mampu menjawab pertanyaan tentang hafalan, melainkan belajar berisi pemahaman mendalam yang melibatkan penggunaan pengetahuan secara aktif dan luwes. Berdasarkan uraian di atas, dalam makalah ini akan dibahas pendekatan yang dapat digunakan untuk melatih siswa berpikir secara kritis dan kreatif.

\section{PEMBAHASAN}

1. Mengapa Keterampilan Berpikir Perlu Diajarkan Meskipun perspektif dan teori belajar kontemporer sangat luas, namun hakikat belajar siswa dalam memahami secara mendalam ide atau konsep dan terpadu secara kognitif. Beberapa alasan mengapa keterampilan berpikir diajarkan adalah sebagai berikut.

a. Berpikir kritis dan kreatif merupakan syarat untuk belajar lintas kurikulum.

b. Banyak tes yang diujikan kepada siswa berisi tentang aplikasi pengetahuan.

c. Belajar berpikir adalah tujuan pembelajaran utama dan terus-menerus diupayakan semenjak dahulu hingga sekarang.

d. Siswa tidak ditekankan untuk memperoleh keterampilan berpikir dan dibiasakan berpikir dalam pembelajaran konvensional.

e. Berpikir yang baik akan membawa kepada pemahaman mendalam terhadap lintas kurikulum.

f. Intelegensi dapat dipelajari karenanya dapat diajarkan. Sebagai guru, kita harus mengajarkan berpikir yang baik kepada siswa.

\section{Self-Regulated Learning (SRL)}

Pelajar yang efektif mengatur berpikir dan belajarnya sendiri. Penelitian tentang SRL menyatakan bahwa belajar yang paling efektif adalah jika siswa mempunyai kontrol terhadap apa dan bagaimana mereka belajar (Zimmerman, 1994). Mempunyai kontrol tidak berarti siswa memilih setiap topik secara acak dan berbuat apa yang mereka inginkan. Seringkali, siswa yang mempunyai Self Regulated Learning mengembangkan keterampilan berpikir kritis 
dan kreatif tertentu dan kriteria yang membuat mereka mampu mengidentifikasi dan investigasi semua topik secara bermakna dan dalam berbagai cara.

SRL dapat dilatihkan kepada siswa secara bertahap dan terus-menerus. Siswa yang mampu mengatur belajar sendiri lebih proaktif dalam belajar. Di samping itu SRL membantu siswa mengembangkan pemahaman materi yang dipelajari dengan baik. Siswa yang memiliki SRL mempunyai kriteria sebagai berikut:

a. Belajarnya lebih terarah pada tujuan (Linder \& Harris, 1992).

b. Mengevaluasi efektifitas pembelajaran.

c. Berpartisipasi aktif dalam proses belajar (Zimmerman, 1989).

\section{Menggunakan Pengetahuan Secara Aktif}

Kognisi adalah proses konstruktif. Siswa tidak dengan mudah memahami informasi dan menggunakannya. Tepatnya, mereka menerima dan belajar melalui proses membuat koneksi aktif. Siswa membangun pemahaman baru dengan menghubungkan pengetahuan yang telah dimiliki dengan yang baru. Temuan penelitian sehubungan dengan melatih belajar konsep secara aktif adalah:

a. Belajar konsep aktif mendorong pemahaman mendalam meskipun tujuannya mengarah pada pengulangan informasi.

b. Pengetahuan yang diperoleh oleh pelajar pasif cenderung lambat dan hanya mampu menjawab pertanyaan tentang ingatan (Bereiter \& Scardamalia, 1985; Perfetto, Bransford, \& Franks, 1983; Perkins \& Martin, 1986).

c. Pelajar aktif cenderung mentransfer dan menerapkan apa yang telah dipelajari ke dalam situasi baru (Salomon \& Perkins, 1989).

\section{Bagaimana Mengajarkan Berpikir}

Ada empat pendekatan mengajarkan berpikir berdasarkan kepada penelitian yang dilakukan oleh the Harvard's Cognitive Skills Group. Keempat pendekatan itu bersama-sama membangun batang tubuh pembelajaran mulai dari merancang kurikulum, implementasi, sampai asesmen. Pendekatan tersebut adalah:

a. Berpikir melalui tema

Mengajar melalui tema adalah teknik pembelajaran membantu siswa mengembangkan keterampilan berpikir dan membantu mengidentifikasi dan dibangun dari tema yang berkembang secara alami. Beberapa tema langsung dari kurikulum seperti mempertimbangkan keputusan, atau memprediksi bagaimana kebijakan tertentu berpengaruh kepada lingkungan. Kadang berkembang dari peristiwa sehari-hari seperti mencari dana untuk wisata. Dalam hal ini tema digunakan sebagai langkah awal mempelajari isu, sementara secara simultan mengajarkan berpikir kritis dan kreatif yang akan membantu memahami topik atau isu secara mendalam.

Berikut beberapa hal yang perlu diperhatikan dalam melaksanakan pembelajaran berpikir melalui tema, yaitu:

1. Tentukan tema dalam kurikulum - tempat di mana keputusan dibuat, bukti di evaluasi atau masalah diidentifikasi. Gunakan tema ini untuk mengajarkan siswa bagaimana bernalar tentang topik yang berbeda.

2. Ajarkan keterampilan berpikir yang baik ketika membantu siswa belajar isu atau topik Pandu dengan membantu mereka mengetahui apa yang dipikirkan tentang masalah tertentu.

3. Tema dapat juga digali dari siswa melalui interaksi dengan siswa. Hal ini akan mendorong mereka mencari tema yang lain dan menumbuhkan pemikir di sekitar mereka.

4. Pilih tema yang memperdalam pembelajaran topik yang lebih generatif. Contoh, tema-nya adalah perpindahan ke negara baru yang akan menghadapi banyak masalah dengan lingkungan baru.

5. Pencarian tema bervariasi. Kadang dimulai dari eksplorasi klasikal, tetapi lain waktu mulai dari eksplorasi individu atau kelompok kecil.

6. Seringkali membantu jika mulai dari ide besar dan kemudian dihubungkan dengan isu-isu.

7. Lebih baik kembali ke tema setelah memilahmilah tema tersebut menjadi bagian-bagian.

8. Cari tema dimana saja. Minta siswa mencari buku, majalah atau sejarah.

\section{b. Berpikir melalui disposisi}

Secara luas berpikir disposisi didefinisikan sebagai kecenderungan terhadap pola perilaku intelektual tertentu. Dahulu, pemikir yang baik ditentukan oleh kemampuan atau keterampilan kognitif. Seringkali, menjadi pemikir yang baik berarti mempunyai kemampuan kritis dan kreatif tertentu. Akan tetapi menjadi pemikir yang baik melibatkan lebih dari sekedar keterampilan kognitif. Pemikir yang baik bergerak dari motivasi, nilai, sikap, dan kebiasaan.

Berpikir melalui disposisi bertujuan mendorong siswa secara konsisten membuat proses 
berpikir berlangsung sehingga memperdalam pemahaman topik yang dipelajari. Berpikir melalui disposisi terdiri atas tiga bagian sebagai berikut.

1. Kemampuan atau keterampilan (kemampuan seseorang menyelesaikan tugas tertentu).

2. Kecenderungan (kecenderungan seseorang untuk terlibat secara kritis dalam berpikir).

3. Sensitivititas, kepekaan seseorang mendeteksi peluang berpikir. Untuk melatih berpikir disposisi siswa, guru harus menekankan kepada ketiga komponen ketika merancang pelajaran, proyek atau kegiatan.

Panduan Pembelajaran berpikir melalui Disposisi sebagai berikut.

1. Lihat peluang dalam kurikulum dimana siswa dapat berpikir secara mendalam tentang topik, ide atau konsep tertentu. Temukan cara siswa menjadi sensitif dalam kesempatan ini.

2. Ajarkan keterampilan berpikir yang baik ketika membantu siswa belajar tentang topik atau isu. Perkenalkan dan jelaskan keterampilan dihubungkan dengan tampilan berpikir seperti menghubungkan pilihan alternatif, mencari perspektif beragam, menemukan masalah, mencari asumsi tersembunyi, dan penalaran pro/kontra.

3. Gali kesempatan berpikir berdasarkan interaksi kelas seperti dari kurikulum. Itu akan membantu siswa melihat peluang berpikir yang baik disekeliling mereka.

4. Interaksi siswa bervariasi. Siswa bekerja dalam kelompok atau secara individu.

5. Perkenalkan siswa dengan perbendaharaan berpikir sebanyak-banyaknya. Jangan terpaku pada pertanyaan, "bagaimana menurutmu...?" tetapi “apa perkiraanmu.....?"

6. Berikan banyak model pemikir yang baik. Mungkin guru dapat mengundang artis, ilmuwan, atau penulis untuk mendiskusikan cara mereka berpikir.

7. Temukan cara menghubungkan nilai, sikap, dan keterampilan dari satu subjek ke lainnya atau dari satu konteks ke lainnya.

\section{c. Berpikir Melalui Transfer}

Transfer berarti menghubungkan apa yang dipelajari atau apa yang diketahui ke dalam konteks lain. Membuat siswa menghubungkan atau menerapkan keterampilan dan konsep yang dipelajari dalam kelas ke subjek atau topik lain adalah salah satu tujuan pembelajaran yang diharapkan. Namun, transfer tidak terjadi sesering yang diharapkan. Siswa yang tidak diarahkan untuk menghubungkan, menerapkan atau ekstrapolasi apa yang mereka ketahui ke dalam konkteks lain. Agar siswa secara konsisten membuat hubungan antar konteks, pembelajaran haruslah menekankan kepada transfer secara langsung. Transfer dapat dipelajari dan diajarkan.

Semakin banyak hubungan yang diidentifikasi dan digali, semakin dalam pemahaman yang diperoleh. Berpikir melalui pendekatan transfer memperkenalkan ide yang akan ditransfer, menjelaskan bagaimana transfer membantu pemahaman, dan menawarkan alat terpusat pada berpikir yang akan melatih rentangan keterampilan berpikir yang diperlukan untuk memperkaya transfer.

Panduan pembelajaran melalui transfer:

1. Mendorong siswa menghubungkan ide kunci atau keterampilan berpikir ke dalam konteks yang hampir sama atau analog. Latihan adalah bagian penting untuk menginternalisasi pengetahuan dan keterampilan.

2. Jelaskan tujuan transfer kepada siswa dari perspektif belajar. Gambarkan berbagai dimensi dari transfer dan bagaimana trasfer mempengaruhi pemahaman. Sekali siswa mengerti bahasa dan tujuan membuat hubungan, mereka akan menjadi sensitif mencari peluang transfer.

\section{d. Berpikir Melalui Asesmen}

Berpikir melalui asesmen adalah pendekatan pembelajaran yang bertujuan untuk menyusun standar untuk berpikir tertentu dan pemahaman performansi yang dicapai siswa dan kemudian membuat standar itu jelas bagi siswa. Asesmen tradisional umumnya tidak mendorong terjadinya berpikir bermakna atau pemahaman. Mereka jarang menjelaskan kepada kita tentang keterampilan berpikir, disposisi atau kecenderungan. Mengenal apa yang diuji sering mengarah kepada apa yang di ajar.

Berpikir melalui pendekatan asesmen sering memberikan informasi, ilustrasi, dan gambaran kepada pengembangan dan menggunakan berpikir sebagai pusat asesmen di dalam kelas. Beberapa ide penting tentang asesmen sebagai berikut.

1. Asesmen tidak sekedar metode untuk mengukur berpikir dan pemahaman siswa terhadap subjek tertentu. Asesmen dapat menjadi pendekatan ampuh untuk mengajar berpikir dengan baik. 
Pembelajaran berpikir dengan asesmen membantu menyusun standar untuk jenis berpikir performansi yang membimbing kepada pemahaman yang mendalam.

2. Berpikir terpusat pada asesmen, memberikan informasi terhadap performansi pemahaman siswa dengan menggarisbawahi kelemahan dan kekuatan berpikir siswa. Informasi tersebut sangat krusial untuk membantu guru menyusun pembelajaran berikutnya.

3. Mengajar berpikir melalui asesmen membantu guru mempertimbangkan target khusus dan jenis berpikir dalam pembelajaran dan proyek yang akan dikembangkan.

4. Asesmen seharusnya berlangsung selama proses pembelajaran. Melaksanakan asesmen pada akhir pembelajaran atau proyek membuang kesempatan siswa untuk memperbaiki kelemahan dan menutup kesenjangan pemahaman.

Panduan pelaksanaan berpikir melalui asesmen adalah sebagai berikut.

1. Jelaskan jenis performansi berpikir yang diharapkan dari siswa.

2. Jelaskan kriteria dan standar berpikir yang baik.

3. Susun standar yang mendorong siswa menunjukkan berpikir yang diinginkan.

4. Beri siswa contoh dan model berpikir terpusat pada asesmen dan jelaskan bagaimana mereka mengukur hasil pemikiran.

5. Ajarkan siswa bagaimana menggunakan asesmen sebagai alat berpikir dan belajar. Libatkan siswa merancang dan membuat asesmen yang digunakan untuk mengevaluasi performansi.

6. Gunakan berpikir terpusat pada asesmen sebagai bentuk evaluasi proses selama pembelajaran. Berikan siswa umpan balik secara teratur pada setiap performansi.

\section{KESIMPULAN}

Berpikir kritis dan kreatif merupakan keterampilan berpikir yang harus dimiliki oleh semua siswa, karena dengan demikian siswa dapat mengkonstruksi pengetahuan. Berpikir kritis dan kreatif dapat diajarkan.

Berpikir melalui tema merupakan pendekatan yang membantu guru dan siswa mengidentifikasi topik atau ide generatif dalam kurikulum dan kemudian mendorong siswa untuk menggali topik dalam cara kritis dan kreatif

Berpikir melalui disposisi merupakan pendekatan yang bertujuan untuk memperkaya dan memperdalam pemahaman dengan melatih tidak hanya keterampilan berpikir tetapi juga kecenderungan, sikap dan kebiasaan.

Berpikir melalui transfer merupakan pendekatan yang bertujuan melaksanakan pembelajaran aktif dan menghubungkan pengetahuan siswa dengan topik dan subjek di dalam dan di luar sekolah.

Berpikir melalui asesmen merupakan pendekatan yang bertujuan untuk meningkatkan "improve thinking performances" dan memperdalam pemahaman melalui rancangan dan pengerjaan asesmen.

\section{DAFTAR PUSTAKA}

Introducing the Thinking Classroom, http://learnweb. harvard.edu/alps/thinking/intro. html\#intro2, diakses pada 25/03/06.

Thinking through Thinkpoints, http://learnweb. harvard.edu \alps \thinking \gettingready_ infusion.html, diakses pada 25/03/06.

Thinking through Dispositions, http:/ / learnweb. harvard.edu \alps \thinking \gettingready_ dispositions.html. Diakses pada 25/03/06

Thinking through Transfer. http:/ / learnweb.harvard. edu \alps \thinking \gettingready_transfer. html. Diakses pada 25/3/06

Thinking through Assessment. http:/ / learnweb. harvard.edu \alps \thinking \gettingready_ assessment.html. Diakses pada 25/03/06

\section{KETERANGAN PENULIS}

Dra. Yurniwati, M.Pd. pada tahun 1998 menyelesaikan studi magister pendidikannya di Jurusan Pendidikan Kelas Awal SD, PPS IKIP Jakarta. 